\title{
Collection of Basic Data on Thorax and Abdomen of Chinese 50th-Percentile Adult Males
}

\author{
Yan Yin ${ }^{1, a}$, Chunsheng $\mathrm{Ma}^{2, b}$, Yongqin Feng ${ }^{3, \mathrm{c}}$, Xiaorui Zhang ${ }^{4, \mathrm{~d}}$ and Lingyun \\ Zeng ${ }^{5, \mathrm{e}}$ \\ 1,3,4,5 Defective Product Administrative Center of AQSIQ, Beijing, 100191, China \\ ${ }^{2}$ Tsinghua University, Beijing, 100084, China

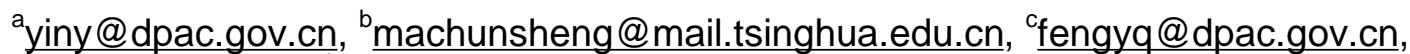 \\ zhangxr@dpac.gov.cn, ${ }^{\mathrm{e}}$ zengly@dpac.gov.cn
}

\begin{abstract}
Keywords: 50th percentile; male; thorax and abdomen; basic data
Abstract. Nowadays, body data model, as a powerful means for occupant crash protection against impact loads, has been widely used to measure and predict the injury degree of those occupants exposed to the crash or explosion of transportation tools such as cars, airplanes, spacecrafts and ships. The numerical model of thorax and abdomen, where vital important organs are accommodated, is one of the most important data sources of body parts. Through choosing the body samples of Chinese 50th-percentile adult males, this paper has, by means of CT and MRI, obtained the density data of vertebras (across both thorax and abdomen), ribs and sternums, as well as the dimensional data of main organs such as heart, liver, spleen, lung, kidney and stomach. These data are expected to serve as basic data of dummies and simulation models of Chinese 50th-percentile adult males, thus applying to the collision injury tests of motor vehicles for occupant protection.
\end{abstract}

\section{Introduction}

In the evaluation of body injuries caused by car crashes, biomechanics is the theoretical basis, and body model is an important evaluation means. Internationally, European countries, the United States and other developed countries have successively developed a series of body data models based on a large number of body feature data and a collection of collision biomechanical tests, and established the injury limit criteria based on European and American body features, thereby introducing various regulations on car crashes. However, the body data models based on European and American body features, which are much different from Chinese body features, are not completely applicable to our country's vehicle safety design. Through statistical analyses, Ren Jindong, Chen Jinghui, Lu Shanbin and Du Xiaoming obtained the main elements of male and female body size distribution in some countries, and proposed a method of describing the boundary of body size distribution and choosing key body data for ergonomic design in the light of the distribution of main elements among the multi-element body data. [1] Hu Huimin, Li Xianxue, Ding Li and Zhao Chaoyi established a finite element model for thorax and abdomen in car collision, and conducted the frontal crash tests. [2] Yin Yan, Ma Chunsheng and Lü Fang, through the thorax/abdomen MRI scanning of Chinese 50th-percentile adult male volunteers, extracted different gray values of bones and internal organs from the scans for 3D CAD geometric modeling, and thus provided basic data for body data modeling. [3] But the above studies failed to acquire basic data of thorax and abdomen. At present, the lack of body data modeling based on Chinese body features makes our country unable to formulate the regulations on impact and collision of the vehicles in collision and of other high-speed transport vehicles, thus imposing serious constraints on the competitiveness of Chinese auto makers in passive safety. Therefore, it is of great significance to develop such a model.

\section{Body Size of Subjects}

The body size data of Chinese adults lay an important foundation for the 3D numerical FEM based on Chinese body features. At present, the body size data in wide use are the data released by the relevant 
national standard in 1988 and the CNIS measurements in 2009. This study takes the body features of Chinese 50th-percentile adult males as an example to compare the database established in 2009 with that in 1988, as shown in the Table 1. The result shows that, over 20 years, the body sizes of 50th-percentile adult males have changed significantly. This study will adopt the sizes in the database established by CNIS in 2009.

Tab. 1 Body Sizes of Chinese 50 ${ }^{\text {th }}$-Percentile Adult Males in 1988 and in 2009

\begin{tabular}{lcccccc}
\hline Data and year & $\begin{array}{c}\text { Height } \\
\text { /cm }\end{array}$ & $\begin{array}{c}\text { Weight } \\
\text { /kg }\end{array}$ & $\begin{array}{c}\text { Bust } \\
\text { /cm }\end{array}$ & $\begin{array}{c}\text { Waist } \\
\text { /cm }\end{array}$ & $\begin{array}{c}\text { Hip } \\
\text { /cm }\end{array}$ & $\begin{array}{c}\text { Shoulder breadth } \\
\text { /cm }\end{array}$ \\
\hline $\begin{array}{l}\text { Data released by the } \\
\text { national standard in 1988 }\end{array}$ & 167.80 & 59.0 & 86.7 & 73.5 & 87.5 & 37.50 \\
$\begin{array}{l}\text { CNIS measurements in } \\
\text { 2009 }\end{array}$ & 169.25 & 64.5 & 93.2 & 81.3 & 93.2 & 38.53 \\
\hline
\end{tabular}

Among various body size features, height, weight and the resulting BMI index shall be given top priority. Therefore, this study takes $169.25 \mathrm{~cm}$ (height) and $64.5 \mathrm{~kg}$ (weight) as the basic features of 50th-percentile adult males to screen the samples of subjects. The subjects were subject to field measurement of 11 body dimensions, as shown in the Table 2.

Tab. 2 Body Size Measurements of Subjects

\begin{tabular}{cccccc}
\hline $\begin{array}{c}\text { Height } \\
\text { /cm }\end{array}$ & $\begin{array}{c}\text { Weigh } \\
\text { /kg }\end{array}$ & $\begin{array}{c}\text { Bust } \\
\text { /cm }\end{array}$ & $\begin{array}{c}\text { Waist } \\
\text { /cm }\end{array}$ & $\begin{array}{c}\text { Hip } \\
\text { /cm }\end{array}$ & $\begin{array}{c}\text { Shoulder breadth } \\
\text { /mm }\end{array}$ \\
\hline 168.20 & 63.3 & 93.0 & 80.2 & 93.1 & 390.2 \\
\hline $\begin{array}{c}\text { Chest breadth } \\
\text { /cm }\end{array}$ & $\begin{array}{c}\text { Chest depth } \\
\text { /cm }\end{array}$ & $\begin{array}{c}\text { Shoulder } \\
\text { height in sitting } \\
\text { posture } \\
\text { /cm }\end{array}$ & $\begin{array}{c}\text { Hip breadth } \\
\text { in sitting } \\
\text { posture } \\
\text { /cm }\end{array}$ & $\begin{array}{c}\text { Hip-knee } \\
\text { distance in } \\
\text { sitting posture } \\
\text { /cm }\end{array}$ & \\
\hline 33.5 & 23.5 & 56.4 & 36.7 & 53.5 \\
\hline
\end{tabular}

\section{Dimensional comparison between subjects and 50th-percentile adult males}

The Table 3 shows the deviations of the subjects' 6 body dimensions (height, weight, bust, waist, hip and shoulder breadth) from $50^{\text {th }}$-percentile, $45^{\text {th }}$-percentile and $55^{\text {th }}$-percentile body dimensions of Chinese adult males measured by CNIS in 2009. Meanwhile, the sample parameters of Toyota THUMS model and GM GHBMC model are compared with the statistical data of American body dimensions, as shown in the Table 4.

Tab. 3 Dimensional Comparison Between Samples and Chinese 50th-Percentile Adult Males

\begin{tabular}{ccccccc}
\hline Data and year & $\begin{array}{c}\text { Height /cm } \\
\text { (Deviation) }\end{array}$ & $\begin{array}{c}\text { Weight /kg } \\
\text { (Deviation) }\end{array}$ & $\begin{array}{c}\text { Bust/cm } \\
\text { (Deviation) }\end{array}$ & $\begin{array}{c}\text { Waist/cm } \\
\text { (Deviation) }\end{array}$ & $\begin{array}{c}\text { Hip/cm } \\
\text { (Deviation) }\end{array}$ & $\begin{array}{c}\text { Shoulder } \\
\text { breadth/cm } \\
\text { (Deviation) }\end{array}$ \\
\hline $\begin{array}{c}\text { Chinese body } \\
\text { dimensions in 1988 }\end{array}$ & 167.8 & 59.0 & 86.7 & 73.5 & 87.5 & 37.5 \\
$\begin{array}{c}\text { Chinese body } \\
\text { dimensions in 2009 }\end{array}$ & 169.3 & 64.5 & 93.2 & 81.3 & 93.2 & 38.5 \\
Sample & 168.2 & 63.3 & 93.0 & 80.2 & 93.1 & 39.0 \\
$(0.6 \%)$ & $(1.8 \%)$ & $(0.2 \%)$ & $(1.4 \%)$ & $(0.1 \%)$ & $(1.2 \%)$ \\
\hline
\end{tabular}


Tab. 4 Dimensional Comparisons between THUMS/GHBMC Models and American 50th-Percentile Adult Males

\begin{tabular}{|c|c|c|c|c|c|c|}
\hline Data and year & $\begin{array}{l}\text { Height /cm } \\
\text { (Deviation) }\end{array}$ & $\begin{array}{l}\text { Weight } / \mathrm{kg} \\
\text { (Deviation) }\end{array}$ & $\begin{array}{c}\text { Bust/cm } \\
\text { (Deviation) }\end{array}$ & $\begin{array}{l}\text { Waist/cm } \\
\text { (Deviation) }\end{array}$ & $\begin{array}{c}\text { Hip/cm } \\
\text { (Deviation) }\end{array}$ & $\begin{array}{c}\text { Shoulder } \\
\text { breadth/cm } \\
\text { (Deviation) }\end{array}$ \\
\hline $\begin{array}{c}\text { American body } \\
\text { dimensions }\end{array}$ & 175.8 & 79.5 & 100.7 & 87.2 & 101.7 & 41.8 \\
\hline THUMS & $\begin{array}{c}173.0 \\
(1.6 \%)\end{array}$ & $\begin{array}{c}77.3 \\
(2.7 \%)\end{array}$ & 1 & 1 & 1 & 1 \\
\hline GHBMC & $\begin{array}{c}174.9 \\
(0.5 \%)\end{array}$ & $\begin{array}{c}78 \\
(1.9 \%)\end{array}$ & $\begin{array}{c}99.7 \\
(1.0 \%)\end{array}$ & $\begin{array}{c}92.1 \\
(5.6 \%)\end{array}$ & 1 & $\begin{array}{c}47.8 \\
(14.3 \%)\end{array}$ \\
\hline
\end{tabular}

The comparisons show that, the maximum deviation of the subjects' 6 body dimensions from those of Chinese $50^{\text {th }}$-percentile males is $1.4 \%$ (waist). The subjects selected by CNIS are better representative than THUMS and GHBMC, which deviate more significantly from American $50^{\text {th }}$-percentile adult males.

\section{Density measurement of main bones in thorax and abdomen}

Currently, CT and MRI are two methods used most widely in the world to obtain the sectional images of human bodies or creatures and even their stereoscopic images through the relevant techniques.

\section{Measurement of vertebra density}

The vertebras involved in this study include 12 thoracic vertebras (T1-T12) and 5 lumbar vertebras (L1-L5). The calculation formula of cancellous bone density is as follows:

$$
\text { Density }=47+1.122 * \mathrm{CT} \text {, in } \mathrm{kg} / \mathrm{m}^{3}
$$

To acquire the average density of cancellous bone, this study chose 6 different vertebras for measurement. For every vertebra, the $\mathrm{CT}$ image at the middle section was chosen, and 3 points on that section were measured. According to the results of all the measuring points, this study calculated and determined the cancellous bone density of vertebras, as shown in the Table 5.

Tab. 5 Results of Vertebra Measurement Points

\begin{tabular}{|c|c|c|c|c|c|c|c|}
\hline \multirow{2}{*}{ Vertebra } & \multicolumn{2}{|c|}{ Point 1} & \multicolumn{2}{|c|}{ Point 2} & \multicolumn{2}{|c|}{ Point 3} & \multirow{2}{*}{$\begin{array}{c}\text { Average } \\
\text { density }\end{array}$} \\
\hline & CT value & Density & CT value & Density & CT value & Density & \\
\hline 1 & 436.42 & 536.6632 & 386.91 & 481.113 & 270.88 & 350.9274 & 456.2345 \\
\hline 2 & 296.36 & 379.5159 & 331.80 & 419.2796 & 426.62 & 525.6676 & 441.4877 \\
\hline 3 & 298.49 & 381.9058 & 321.23 & 407.4201 & 467.94 & 572.0287 & 453.7848 \\
\hline 4 & 374.58 & 467.2788 & 359.54 & 450.4039 & 793.91 & 937.767 & 618.4832 \\
\hline 5 & 472.84 & 577.5265 & 489.96 & 596.7351 & 849.38 & 1000.004 & 724.7553 \\
\hline 6 & 485.49 & 591.7198 & 391.01 & 485.7132 & 804.29 & 949.4134 & 675.6155 \\
\hline
\end{tabular}

\section{Measurement of rib density}

For the ribs consisting of both compact bone and cancellous bone, this study measured and calculated the densities of the two elements in the same way as vertebras.

For cancellous bone, the calculation formula of its density is as follows:

$$
\text { Density }=114+0.916 * \mathrm{CT} \text {, in } \mathrm{kg} / \mathrm{m}^{3}
$$

For compact bone, its longitudinal modulus of elasticity shall be calculated by using the following equation before determining its density:

$$
\mathrm{E} 3=296+5.20 * \mathrm{CT} \text {, in } \mathrm{MPa}
$$


On this basis, the density of compact bone can be calculated according to the relationship between E3 and the density given in the literature, as shown below:

$$
\mathrm{E} 3=-3.842+0.013 * \text { Density }
$$

The results are given in the Table 6 .

Tab. 6 Results of Rib Measurement Points

\begin{tabular}{|c|c|c|c|c|c|c|c|c|}
\hline \multirow[b]{2}{*}{ Rib } & \multicolumn{3}{|c|}{ Point 1} & \multicolumn{3}{|c|}{ Point 2} & \multirow{2}{*}{$\begin{array}{c}\text { Average } \\
\text { density of } \\
\text { cancellous } \\
\text { bone } \\
\end{array}$} & \multirow{2}{*}{$\begin{array}{l}\text { Average } \\
\text { density of } \\
\text { compact } \\
\text { bone }\end{array}$} \\
\hline & $\begin{array}{c}\text { CT } \\
\text { value }\end{array}$ & $\begin{array}{c}\text { Density of } \\
\text { cancellous } \\
\text { bone } \\
\end{array}$ & $\begin{array}{c}\text { Density of } \\
\text { compact } \\
\text { bone }\end{array}$ & $\begin{array}{c}\text { CT } \\
\text { value }\end{array}$ & $\begin{array}{c}\text { Density of } \\
\text { cancellous } \\
\text { bone }\end{array}$ & $\begin{array}{c}\text { Density of } \\
\text { compact } \\
\text { bone }\end{array}$ & & \\
\hline 1 & 563.1 & 629.7996 & 1543.5477 & 738.05 & 790.0544 & 1526.1917 & 709.927 & 1534.87 \\
\hline 2 & 678.61 & 735.6076 & 1458.7477 & 547.01 & 615.0617 & 1449.7757 & 675.335 & 1454.26 \\
\hline 3 & 559.03 & 626.0723 & 1410.9157 & 606.69 & 669.7283 & 1517.3157 & 647.900 & 1464.12 \\
\hline 4 & 679.06 & 736.0201 & 1415.2597 & 587.63 & 652.2699 & 1422.3557 & 694.145 & 1418.81 \\
\hline 5 & 719.78 & 773.3196 & 1431.5477 & 712.92 & 767.0358 & 1428.8037 & 770.178 & 1430.18 \\
\hline 6 & 440.57 & 517.5621 & 1494.5357 & 543.46 & 611.8096 & 1492.0237 & 564.686 & 1493.28 \\
\hline
\end{tabular}

\section{Measurement of sternum density}

The calculation results of sternum density are obtained in a way similar to rib density calculation by choosing the points on differnet sternum sections in proper order for measurement and then calculating the density in accordance with the formula given in the literature. The measurement results of sternum density are shown in the Table 7.

Tab. 7 Results of Sternum Measurement Points

\begin{tabular}{|c|c|c|c|c|c|c|c|c|}
\hline \multirow[b]{2}{*}{ Rib } & \multicolumn{3}{|c|}{ Point 1} & \multicolumn{3}{|c|}{ Point 2} & \multirow{2}{*}{$\begin{array}{c}\text { Average } \\
\text { density of } \\
\text { cancellous } \\
\text { bone }\end{array}$} & \multirow{2}{*}{$\begin{array}{c}\text { Average } \\
\text { density of } \\
\text { compact } \\
\text { bone }\end{array}$} \\
\hline & $\begin{array}{c}\mathrm{CT} \\
\text { value }\end{array}$ & $\begin{array}{c}\text { Density of } \\
\text { cancellous } \\
\text { bone }\end{array}$ & $\begin{array}{c}\text { Density of } \\
\text { compact } \\
\text { bone }\end{array}$ & $\begin{array}{c}\text { CT } \\
\text { value }\end{array}$ & $\begin{array}{c}\text { Density of } \\
\text { cancellous } \\
\text { bone }\end{array}$ & $\begin{array}{c}\text { Density of } \\
\text { compact } \\
\text { bone }\end{array}$ & & \\
\hline 1 & 635.98 & 696.55768 & 1596.86 & 488.25 & 561.237 & 1456.63 & 592.4038 & 1526.75 \\
\hline 2 & 569.23 & 635.41468 & 1588.69 & 469.36 & 543.9338 & 1446.57 & 552.3873 & 1517.63 \\
\hline 3 & 462.3 & 537.4668 & 1439.84 & 475.69 & 549.732 & 1450.24 & 506.5784 & 1445.04 \\
\hline 4 & 498.6 & 570.7176 & 1485.25 & 600.68 & 664.2229 & 1556.28 & 585.6988 & 1520.77 \\
\hline 5 & 522.3 & 592.4268 & 1490.32 & 597.6 & 661.4016 & 1552.78 & 595.0134 & 1521.55 \\
\hline 6 & 477.6 & 551.4816 & 1446.56 & 587.6 & 652.2416 & 1547.39 & 569.5408 & 1496.98 \\
\hline
\end{tabular}

\section{Dimensions of main organs in thorax and abdomen}

On the basis of MRI results, this study measured main organs in thorax and abdomen to obtain the dimensions of those organs. To ensure the measurement accuracy, the relevant work was done in Mimics, where the dimension boundaries could be determined through multi-directional section adjustment.

Heart. The heart size was measured as $92.80 \mathrm{~mm} * 89.87 \mathrm{~mm} * 137.87 \mathrm{~mm}$, as shown in the Fig.1. 


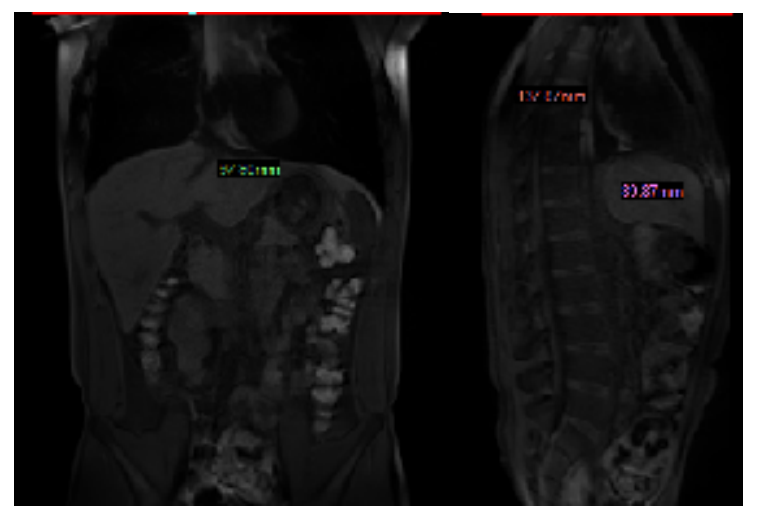

Fig.1 Measurement of Heart Size

Liver. The liver size was measured as $186.57 \mathrm{~mm} * 156.29 \mathrm{~mm} * 166.22 \mathrm{~mm}$, as shown in the Fig.2.

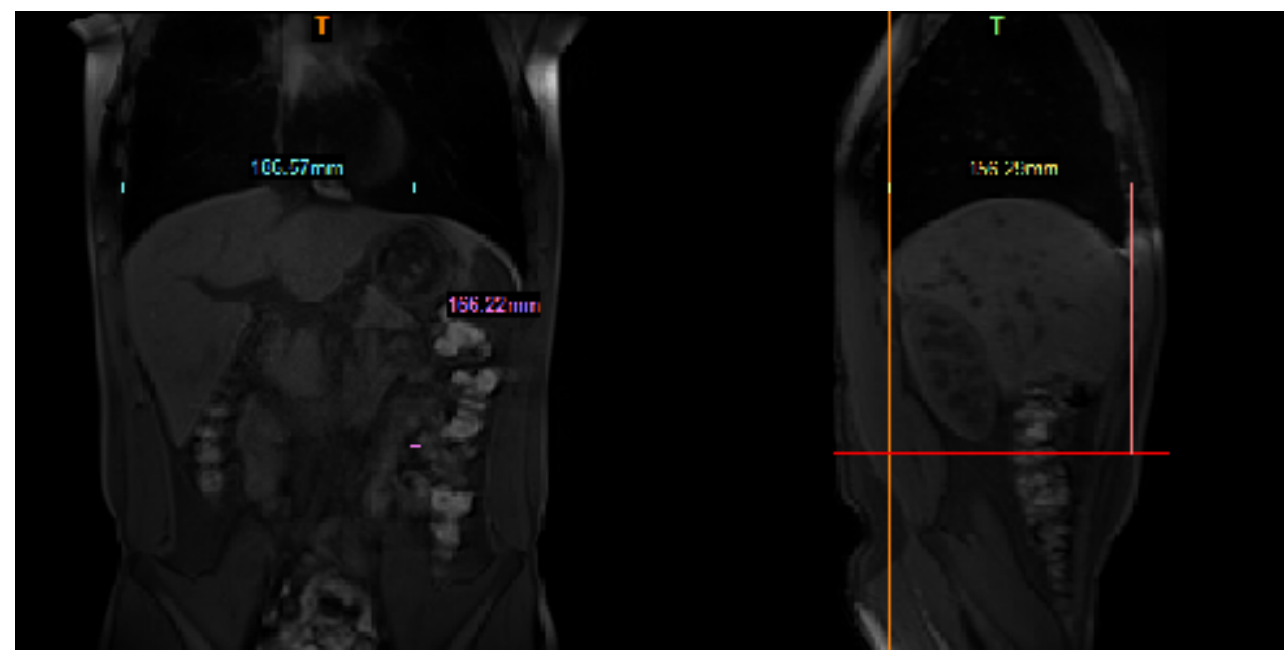

Fi g. 2 Measurement of Liver Size

Spleen. The spleen size was measured as $115.26 \mathrm{~mm} * 110.38 \mathrm{~mm} * 94.84 \mathrm{~mm}$, as shown in the Fig.3.

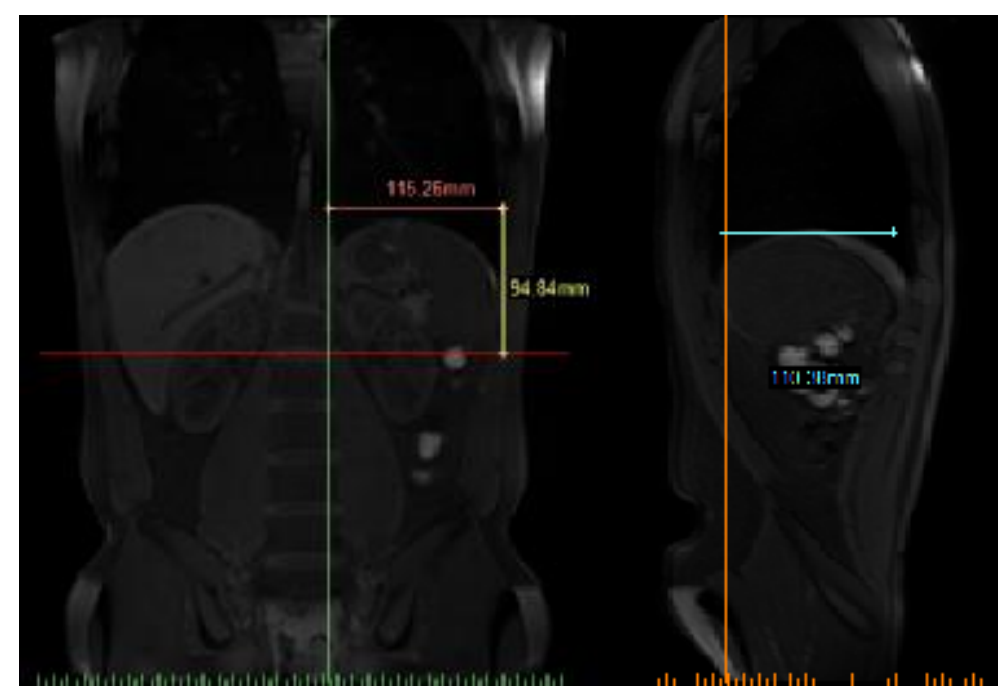

Fig.3 Measurement of Spleen Size

Lung. The lung size was measured as $111.36 \mathrm{~mm} * 152.38 \mathrm{~mm} * 163.29 \mathrm{~mm}$, as shown in the Fig.4. 


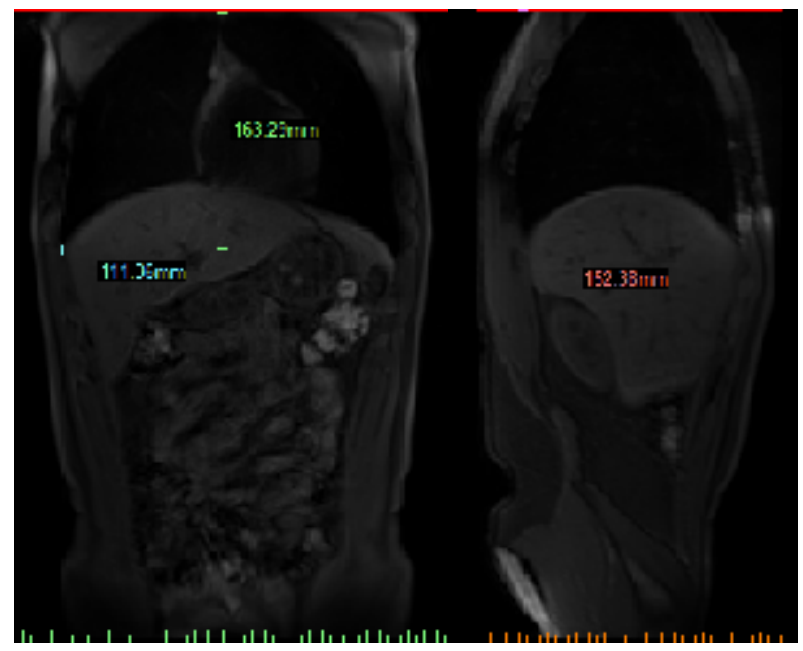

Fig.4 Measurement of Lung Size

Kidney. The kidney size was measured as $67.40 \mathrm{~mm} * 59.59 \mathrm{~mm} * 88.98$, as shown in the Fig.5.

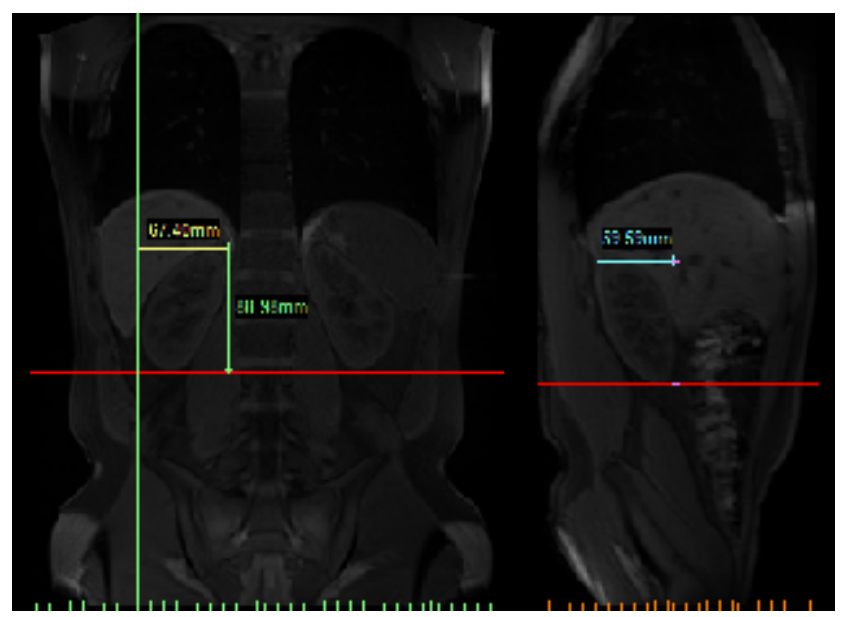

Fig.5 Measurement of Kidney Size

Stomach. The stomach size was measured as $93.77 \mathrm{~mm} * 36.14 \mathrm{~mm} * 63.56 \mathrm{~mm}$, as shown in the Fig.6.

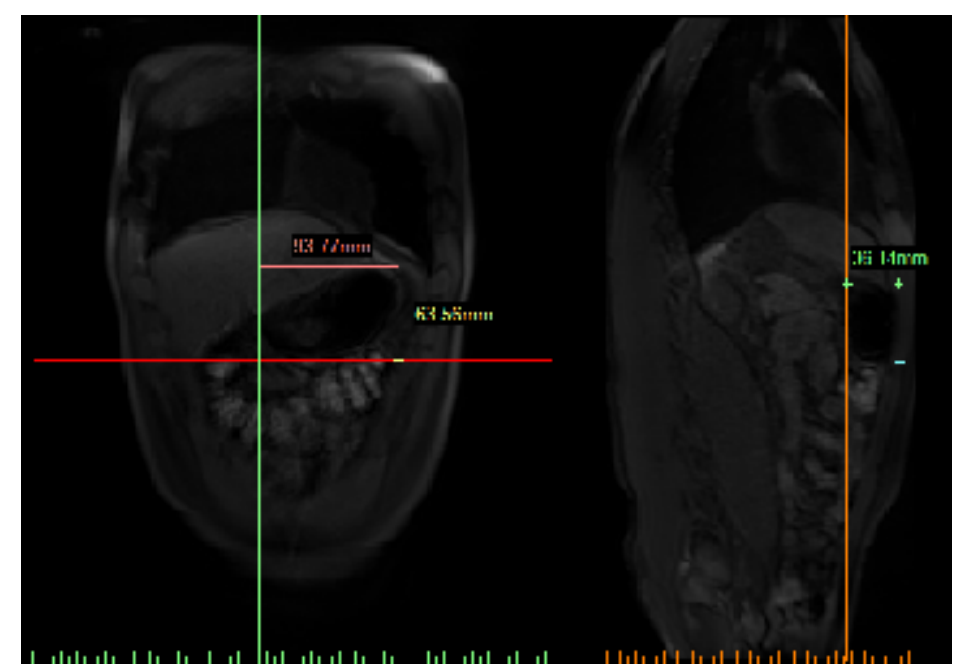

Fig.6 Measurement of Stomach Size 


\section{Acknowledgements}

This work was financially supported by the Fundamental Research Funds of China National Institute of Standardization titled Automotive Product Safety and Recall Technology Research Annual Report Compiled (No. 282014Y-3355).

\section{References}

[1] Jindong Ren, Jinghui Chen, Shanbin Lu et al.: Automotive Engineering, 6(2013) (In Chinese)

[2] Huimin Hu, Xianxue LI, Li Ding et al.: Standard Science, 7(2015) (In Chinese)

[3] Yan Yin, Chunsheng Ma, Fang LV: Standard Science, 7(2015) (In Chinese) 